\title{
Assessment of Awareness, Knowledge and Attitudes about the Importance of Cadaver and Cadaver Donation: Report of Izmir, Turkey
}

\author{
Evaluación de la Conciencia, el Conocimiento y las Actitudes sobre la Importancia \\ del Cadáver y la Donación de Cadáveres: Informe de Izmir, Turquía
}

Kübra Erdogan¹ Kemal Emre Özen; Hayrullah Yildiz ${ }^{2}$ \& Mehmet Ali Malas ${ }^{1}$

ERDOGAN, K.; ÖZEN, K. E.; YILDIZ, H. \& MALAS, M. A. Assessment of awareness, knowledge and attitudes about the importance of cadaver and cadaver donation: Report of Izmir, Turkey. Int. J. Morphol., 38(4):831-837, 2020.

SUMMARY: The aim of this study was to evaluate the awareness, knowledge level and attitudes of the community in I'zmir/ Turkey about cadaver donation in medical education. A cross-sectional study was carried out. Randomly chosen 245 participants answered twenty items in the questionnaire providing information about their demographics (5 items), awareness and knowledge (10 items), and attitudes (5 items) about body donation. The questionnaire was applied face-to-face. Descriptive statistics presented. Student T test and One-Way ANOVA test were used for statistical analysis. 123 (50.2\%) participants were male and 159 (64.9\%) were between 30 to 59 years old. $185(75.5 \%)$ respondents knew what the word "cadaver" means. When asked where they would apply if they decided to donate their body, 104 (42.4\%) of the participants gave the answer "state hospital". The mean score of awareness and knowledge about importance of cadaver and body donation (AWKL-Score) was 0.41 \pm 0.24 (min:0.00, max:0.90). AWKL-Score was statistically higher in the youngest (18-29 y) and oldest (>60 y) compared to the other age groups (F:4.115; p:0.007). AWKL-Score increased as the level of education increased. The highest AWKL-Score was at post-graduate level (Level 7,8) (F:22.997; p<0.001). The AWKL-Score was higher in public employees and students compared to other occupational groups (F:5.930; $<<0,001)$. The answers to the questionnaire were important indicators of how much society needs to be informed regarding body donation.

KEY WORDS: Body donation; Cadaver; Awareness and knowledge level; Attitude; Anatomy education; Medical education.

\section{INTRODUCTION}

In medical education, cadaver [(k-dav'r) (L., from cadere to fall, to perish) a dead body; generally applied to a human body (Dorland, 2011) is an indispensable material of medical education. Education on the human body is a "sine qua non" of anatomy. Scientific studies have been conducted on cadavers for centuries. Newly developed technological training materials do not appear to replace dissection and cadaver work. For a qualified anatomical and medical education, the students must work on a cadaver. The number of cadavers used in medical school education in Turkey is far below the desired level (Gürses et al., 2018). Unfortunately, in some medical faculties, anatomy education is performed without cadavers. In developed countries, cadavers are provided by public donations. Thousands of people donate their bodies to medical schools for educational and scientific purposes. This is an important indicator of societies' belief and support in science.
Devoting the body to the development of humanity and science is the most valuable gift that a dead person can give to the living, which cannot be measured by any material value. At this point, voluntary body donors, who want to support scientific studies have a big duty. Within the framework of the law, as in other developed countries, in Turkey, after death, people can donate their body for educational and scientific purposes. In addition, the body of the person known to have willing can be donated for the same purpose with the approval of all heirs. The work on the donated bodies is carried out with the utmost respect within the ethical rules, and then the funeral procedures are performed according to the request of the donor. Despite the above, it is remarkable that the number of body donations is not at the desired level in Turkey.

While the number of donors in Europe and North

\footnotetext{
${ }^{1}$ Department of Anatomy, Faculty of Medicine, Izmir Katip Çelebi University, Çigli Ana Yerleskesi 35620 Çigli/Izmir, Turkey.

${ }^{2}$ Independent researcher, address: Sair Esref Bulvarı Ismet Kaptan Mahallesi 3/2 Umur Bey Is Merkezi Kat 2 Konak/Izmir, Turkey
} 
America is quite high, unfortunately this number is very low in our country. Accordingly, the number of cadavers obtained from voluntary donors in medical education is extremely low (Gürses et al.). Undoubtedly, these difficulties in medical education on cadavers can be overcome by increasing the number of body donors. It is very important to investigate the reasons for not increasing the number of cadaver donors in the society and to propose solutions in this regard (Wight et al., 2000; Dinsmore et al., 2001; Gürses et al.). This study aimed to assess the awareness, knowledge and attitudes about the importance of cadaver in medical education and cadaver donation.

\section{MATERIAL AND METHOD}

A cross-sectional study was conducted in 2015 and 2016. The data of the study was collected with a questionnaire form prepared by the researchers in accordance with the purpose of the study and the literature (Emson, 1987; Kleinman \& Lowy, 1989; Wight et al.; Dinsmore et al.; Bøgh \& Madsen, 2005; Mekahli et al., 2009; da Rocha et al., 2013; Caplan, 2014; Gatica-Araneda \& Alfaro-Toloza, 2014; Dalal, 2015; Saha et al., 2015; Subasinghe \& Jones, 2015; Abbasi Asl et al., 2017; Bamaç et al., 2018; Ciliberti et al., 2018; Gürses et al.; Wingfield, 2018) [see additional file 1 (English translation of the questionnaire form)]. The questionnaire consists of three sections (Tabla I). The first section includes five questions (Q1-Q5) that question about some sociodemographic characteristics (gender, age, educational status, marital status, occupation). Education status categories are formed by grouping the levels reported at ISCED 2011 (UNESCO, 2012). Awareness and level of knowledge were questioned with ten items (Q6-Q15) in the second part. To determine the awareness and knowledge level, the answers are scored by giving 1 point for the "yes", and 0 point for the "no". Thus, the average level of awareness and knowledge (AWKL-Score) was calculated between 0 and 1 . In the third part, the attitudes towards cadaver donation was questioned with a total of five questions (Q16-Q20). In the second and third part of the survey, thoughts about the cadaver, body donation, body donation campaigns and news were investigated as well as the thoughts for requirement of cadaver in medical faculties in our country and cadaver imports. In addition, it was investigated whether the participants knew the procedures related to cadaver donation, cadaver use and post-donation. Participants were asked to answer questions about their knowledge and behavior about body donation, both religiously and sociologically.

The survey population were adults living in Izmir/ Turkey who had no impairment answering the questions.
The population of Izmir in 2015 is 4,168,415 and Izmir's population aged 18 and over is estimated approximately $3,334,732$. As considering unknown prevalence in general population, $50 \%$ prevalence, $95 \%$ confidence interval and $6 \%$ margin of error were accepted for sample size calculating. Thus, the sample size was calculated as 196. For the research, people living in the center of Izmir were randomly reached in crowded bazaars and shopping centers. A sample group was formed with 245 people who agreed to participate in the study with verbal consent. The questionnaire was applied to the participants by face to face interview technique. Each interview lasted approximately 15-20 minutes.

The data were analyzed using IBM SPSS Statistics v25 (SPSS Inc, Chicago, IL) software package. Descriptive statistics (frequencies and percentages) were used to describe the obtained results. When comparing mean scores for groups two-tailed paired-sample t-test (when comparing two groups' means) was used. One-way Analysis of Variance (ANOVA) test was used to compare the means for more than two groups and post hoc analysis was performed in paired comparisons. Statistical significance was set at $\mathrm{p}<0.05$. and a $\mathrm{p}$-value $<0.001$ as highly significant.

\section{RESULTS}

The majority of participants (n: 245) were aged between 45-59 years (n: 80, 32.7\%), male (n: 123, 50.2\%), held a Bachelor's or equivalent degree (Level 6) (n: 96, 39.2 $\%$ ), married (n: 178, $72.7 \%$ ), and public employee (n: 49, $20 \%)$. The participants' some sociodemographic characteristics are shown in Table II.

$75.5 \%$ of the participants knew what the word cadaver means. The percentage of those who knew they could donate their body (as cadaver) was $66.9 \%$. With regards to the question "Are you aware of the cadaver donation campaigns?", $20.4 \%$ (n:50) of the participants responded yes. With regards to the question "Do you know that Turkish Universities import donated cadavers from abroad and pay transfer fees?", $17.6 \%$ (n:43) of the participants responded yes. With regards to the question "Are you aware of the fatwa of the Presidency of Religious Affairs regarding the body donation is permissible in Sharia (Islamic law)?", $29.8 \%$ (n:73) of the participants responded yes. Table III shows the distribution of the answers of the participants to the questions measuring the level of awareness and knowledge about importance of cadaver and cadaver donation. 
Tabla I. Questionnarie on awareness, knowledge and attitude about the importance of cadaver and cadaver donation

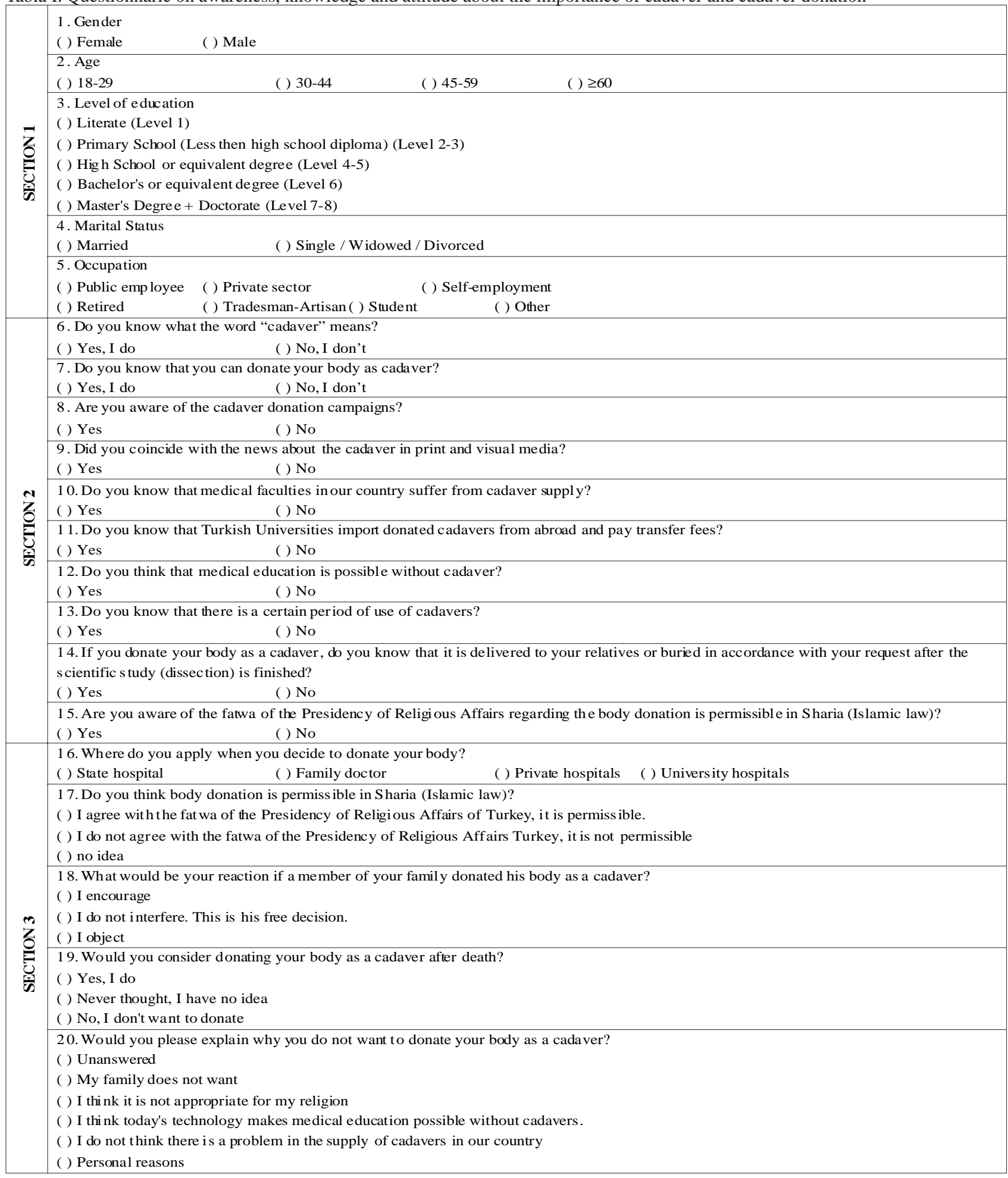

The AWKL-Score of the all participants was $0.41 \pm 0.24$ (min:0.00, max:0.90). The AWKL-Scores for the youngest (18y-29 y) and the oldest (60 y and older) age groups were $0.49 \pm 0.22$ and $0.48 \pm 0.26$, respectively, and were significantly higher (F:4.115; p:0.007) than the other age groups. The AWKL-Score was $0.39 \pm 0.25$ in males and 
$0.44 \pm 0.23$ in females, and no statistically significant difference was found between the genders (t:1.451; p:0.184). The highest AWKL-Score was at the group of master's degree or doctorate (Level 78) (F:22.997; $p<0.001)$. It was observed that the higher the education level, the higher the AWKL-Score. The AWKLScore was $0.40 \pm 0.25$ in married and $0.46 \pm 0.21$ in single/widowed/divorced, and no statistically significant difference was found between the groups ( $\mathrm{t}: 1.934$; p:0.055). AWKL-Score was significantly higher in public employees $(0.55 \pm 0.21)$ and students $(0.48 \pm 0.20)$ than in other occupational groups (F:5.930; $\mathrm{p}<0.001$ ). Table IV shows AWKL-Scores of the participants about the importance of cadaver and cadaver donation according to some sociodemographic factors

When asked where they would apply, if they decided to donate their body, $42.4 \%$ (n: 104) of the participants gave the answer "state hospital". With regards to the question "Do you think cadaver donation is permissible in Sharia (Islamic law)?", $40.0 \%$ (n: 98) of the participants responded "I agree with the fatwa of the Presidency of Religious Affairs of Turkey, it is permissible". When asked what their reaction would be if a member of their family donates his/her body as a cadaver, $53.1 \%$ (n: 104) of the participants gave the answer "I do not interfere. This is his/her free decision." $33.4 \%$ (n: 82) of the participants answered "no" the question "Would you
Table II. Sociodemographic characteristics of participants.

\begin{tabular}{lll}
\hline Sociodemographic characteristics $(\mathrm{n}=245)$ & $\mathrm{n}$ & $(\%)$ \\
\hline Age (years) & 60 & $24.5 \%$ \\
$18-29$ & 79 & $32.2 \%$ \\
$30-44$ & 80 & $32.7 \%$ \\
$45-59$ & 26 & $10.6 \%$ \\
$\geq 60$ & & \\
Gender & 123 & $50.2 \%$ \\
$\quad$ Male & 122 & $49.8 \%$ \\
$\quad$ Female & & \\
Level of education & 5 & $2.0 \%$ \\
$\quad$ Literate (Level 1) & 52 & $21.2 \%$ \\
$\quad$ Primary School (Less then high school diploma) (Level 2-3) & 73 & $29.8 \%$ \\
High School or e quivalent degree (Level 4-5) & 96 & $39.2 \%$ \\
Bachelor's or equvalent degree (Level 6) & 19 & $7.8 \%$ \\
Master's Degree + Doctorate (Level 7-8) & & \\
Marital Status & 67 & $27.3 \%$ \\
$\quad$ Single / Widow / Divorced & 178 & $72.7 \%$ \\
$\quad$ Married & & \\
Occupation & 49 & $20.0 \%$ \\
Public employee & 41 & $16.7 \%$ \\
Private sector & 15 & $6.1 \%$ \\
Self-employment & 30 & $12.2 \%$ \\
Retired & 26 & $10.6 \%$ \\
Tradesman- Artisan & 37 & $15.1 \%$ \\
Student & 47 & $19.3 \%$ \\
$\quad$ Other & &
\end{tabular}

consider donating your body as a cadaver after death?". When asked their reason for not donating their body, almost half of the participants $(45.7 \%)$ left the question unanswered. Table $\mathrm{V}$ shows the distribution of the responses of the participants to the questions showing their attitudes about cadaver donation.

Table III. The distribution of the answers given by the participants to the questions measuring the level of awareness and knowledge about the importance of cadaver and cadaver donation.

\begin{tabular}{clcc}
$\begin{array}{c}\text { Question } \\
\text { Id }\end{array}$ & Questions (N:245) & $\begin{array}{c}\text { Yes } \\
\text { n ( \%) }\end{array}$ & $\begin{array}{c}\text { No } \\
\text { n ( \%) }\end{array}$ \\
\hline 6 & Do you know what the word "cadaver" means? & $185(75.5 \%)$ & $60(24.5 \%)$ \\
7 & Do you know that you can donate your body as cadaver? & $164(66.9 \%)$ & $81(33.1 \%)$ \\
8 & Are you aware of the cadaver donation campaigns? & $50(20.4 \%)$ & $195(79.6 \%)$ \\
9 & Did you coincide with the news about the cadaver in print and visual & $108(44.1 \%)$ & $137(55.9 \%)$ \\
10 & Do you know that medical faculties in our country suffer from & $141(57.6 \%)$ & $104(42.4 \%)$ \\
11 & Do you know that Turkish Universities import donated cadavers & $43(17.6 \%)$ & $202(82.4 \%)$ \\
12 & Do you think that medical education is possible without cadaver? & $72(29.4 \%)$ & $173(70.6 \%)$ \\
13 & Do you know that there is a certain period of use of cadavers? & $110(44.9 \%)$ & $135(55.1 \%)$ \\
& If you donate your body as a cadaver, do you know that it is & $73(29.8 \%)$ & $172(70.2 \%)$ \\
14 & delivered to your relatives or buried in accordance with your request & & \\
& after the scientific study (dissection) is finished? & $73(29.8 \%)$ & \\
& Are you aware of the fatwa of the Presidency of Religious Affairs of & & \\
& Turkey regarding the body donation is permissible in Sharia (Islamic & & \\
& law)? & &
\end{tabular}


Table IV. Awareness and Knowledge Level Scores (AWKL-Score) of the participants about the importance of cadaver and cadaver donation according to some sociodemographic factors.

\begin{tabular}{|c|c|c|}
\hline Sociodemographic Characteristics & $\begin{array}{c}\text { Awareness and knowledge } \\
\text { score } \\
\text { Mean } \pm \text { SD }\end{array}$ & $\begin{array}{l}\text { Statistical Analysis } \\
\text { t score / F statistic } ; p\end{array}$ \\
\hline \multicolumn{3}{|l|}{ Age (years) } \\
\hline $18-29$ & $0.49 \pm 0.22$ & \multirow{4}{*}{$4.115 ; 0.007$} \\
\hline $30-44$ & $0.38 \pm 0.25$ & \\
\hline $45-59$ & $0.38 \pm 0.23$ & \\
\hline$\geq 60$ & $0.48 \pm 0.26$ & \\
\hline \multicolumn{3}{|l|}{ Gender } \\
\hline Male & $0.39 \pm 0.25$ & \multirow{2}{*}{$1.451 ; 0.184$} \\
\hline Female & $0.44 \pm 0.23$ & \\
\hline \multicolumn{3}{|l|}{ Level of education } \\
\hline Literate (Level 1) & $0.12 \pm 0.04$ & \multirow{5}{*}{$22.977 ;<0.001$} \\
\hline Primary School (Less then high school diploma) (Level 2-3) & $0.22 \pm 0.23$ & \\
\hline High School or equivalent degree (Level 4-5) & $0.41 \pm 0.22$ & \\
\hline Bachelor's or equvalent degree (Level 6) & $0.49 \pm 0.19$ & \\
\hline Master's Degree + Doctorate (Level 7-8) & $0.65 \pm 0.17$ & \\
\hline \multicolumn{3}{|l|}{ Marital Status } \\
\hline Single / Widow / Divorced & $0.46 \pm 0.21$ & \multirow[t]{2}{*}{$1.934 ; 0.055$} \\
\hline Married & $0.40 \pm 0.25$ & \\
\hline \multicolumn{3}{|l|}{ Occupation } \\
\hline Public Employee & $0.55 \pm 0.21$ & \multirow{9}{*}{$5.930 ;<0.001$} \\
\hline Private sector & $0.35 \pm 0.25$ & \\
\hline Self-employment & $0.37 \pm 0.24$ & \\
\hline Retired & $0.42 \pm 0.23$ & \\
\hline Tradesman-Artisan & $0.33 \pm 0.24$ & \\
\hline Student & $0.48 \pm 0.20$ & \\
\hline Other & $0.33 \pm 0.24$ & \\
\hline \multirow{2}{*}{ Total } & $0.41 \pm 0.24$ & \\
\hline & (min: 0.00. max: 0.90) & \\
\hline
\end{tabular}

Table V. Distribution of the answers given by the participants to the questions showing their attitudes towards cadaver donation.

\begin{tabular}{|c|c|c|c|}
\hline Question Id & Questions (n:245) & $\mathrm{n}(\%)$ & \\
\hline \multirow{4}{*}{16} & \multirow{4}{*}{$\begin{array}{l}\text { Where do you apply when you } \\
\text { decide to donate your body? }\end{array}$} & $104(42.4 \%)$ & State hospital \\
\hline & & $34(14.0 \%)$ & Family doctor \\
\hline & & $16(6.5 \%)$ & Private hospitals \\
\hline & & $91(37.1 \%)$ & University hospitals \\
\hline \multirow{3}{*}{17} & \multirow{2}{*}{$\begin{array}{l}\text { Do you think cadaver donation } \\
\text { is permissible in Sharia }\end{array}$} & $98(40.0 \%)$ & I agree with the fatwa of the Presidency of Religious Affairs of \\
\hline & & $51(20.8 \%)$ & I do not agree with the fatwa of the Presidency of Religious \\
\hline & \multirow{4}{*}{$\begin{array}{l}\text { Islamic law }) \text { ? } \\
\text { What would be your reaction if } \\
\text { a member of your family } \\
\text { dnnated his hodv as a cad aver? } \\
\text { Would you consider donating }\end{array}$} & $96(39.2 \%)$ & No idea \\
\hline \multirow{3}{*}{18} & & $33(13.5 \%)$ & I encourage \\
\hline & & $130(53.1 \%)$ & I do not interfere. This is his free decision. \\
\hline & & $\begin{array}{l}82(33.4 \%) \\
39(15.9 \%)\end{array}$ & $\begin{array}{l}\text { I object. } \\
\text { Yes, I do }\end{array}$ \\
\hline \multirow[t]{2}{*}{19} & \multirow{2}{*}{$\begin{array}{l}\text { your body as a cadaver after } \\
\text { death? }\end{array}$} & $73(29.8 \%)$ & Never thought, I have no idea \\
\hline & & $133(54.3 \%)$ & No, I don't want to donate \\
\hline \multirow{4}{*}{20} & \multirow{4}{*}{$\begin{array}{l}\text { Would you please explain why } \\
\text { you do not want to donate your } \\
\text { body as a cadaver? }\end{array}$} & $\begin{array}{l}112(45.7 \%) \\
9(3.7 \%) \\
28(11.4 \%)\end{array}$ & $\begin{array}{l}\text { Unanswered } \\
\text { My family does not want } \\
\text { I think it is not appropriate for my religion }\end{array}$ \\
\hline & & $12(04.9 \%)$ & $\begin{array}{l}\text { I think today's technology makes medical education possible } \\
\text { without cadavers. }\end{array}$ \\
\hline & & $11(4.5 \%)$ & $\begin{array}{l}\text { I do not think there is a problem in the supply of cada vers in } \\
\text { our country }\end{array}$ \\
\hline & & $73(29.8 \%)$ & Personal reasons \\
\hline
\end{tabular}




\section{DISCUSSION}

Awareness and knowledge level of the individuals are important factors for developing positive attitudes towards body donation. Therefore, encouraging works will have a positive effect on the cadaver donation and increase the donation rate (Bamaç et al.). "Yes" answers with a rate of $75.5 \%$ to the question "Do you know what the word cadaver means?" does not mean that the participants have a high level of knowledge. Because "yes" answer to the other questions in the questionnaire measuring the knowledge level of the participants varies just between $17.6 \%$ and $66.9 \%$. These results show that the participants have accurate information about cadaver donation at a maximum level of two thirds, which should be interpreted as an insufficient level.

The proportion of the participants considering applying to the state hospital and family physician $(42.40 \%$ and 13.98 $\%$, respectively) for body donation shows that the personnel working in these institutions should be informed about body donation and related procedures.

The percentage (39.2\%) of the answer "no idea" to the question "Do you think body donation is permissible in Sharia (Islamic law)?" provides evidence that the activities of the Presidency of Religious Affairs of Turkey have not yet achieved the desired level.

When the educational level of the participants was evaluated, it was observed that the level of knowledge of the group of literate and primary school degree was inadequate. When the education level group was evaluated in terms of awareness and knowledge level score (AWKL-Score), it was determined that as the level of education increases, knowledge level score increases. In addition, it was determined that the knowledge level of the self-employed group was quite low in the occupational groups. Therefore, it was concluded that these groups should be informed about body donation.

Low body donation rates determined in this study shows that, in Turkey, making significant progress is needed.

The participants' awareness and knowledge level (AWKL-Scores) about cadaver and cadaver donation was evaluated as quite low $(0.41 \pm 0.24)$. From this, it was concluded that the community should be informed about body donation. When the relationship between AWKL-Scores and age was evaluated, it was observed that the middle age group should be informed more than the younger (18-29y) and 60 and older age group.

In parallel with the advancement of medicine, the need for cadavers is increasing in the fields of anatomy and medical research. Various methods are used in cadaver procurement in different countries and medical schools (Kleinman \& Lowy, Mekahli et al.; Subasinghe \& Jones). In the literature, from an ethical and broad perspective, it is suggested that cadavers obtained from donations will be more appropriate (Emson; Caplan). Throughout the history of anatomy and medicine, obtaining cadavers for education has been an important problem. As a result of ethical discussions, the most accurate method for cadaver procurement was considered to be voluntary donation of the human body or part of it (Bøgh \& Madsen; Dalal). Today, cadavers used in medical schools in almost all developed countries are the corpses of people who voluntarily donated their bodies to science. The number of donations has increased in these countries in recent years and has exceeded the storage and/or usage capacity of laboratories. Therefore, there are medical schools that suspend their donation programs for a certain period. In addition, in the USA, the donation programs of scientific institutions for the procurement of cadavers to medical studies or the provision of services from private supply companies are being discussed (Wingfield). It is reported that strong body donation programs are needed in countries where there the body donations are not at desired level (Gatica-Araneda \& Alfaro-Toloza).

There is inadequate published information about body donation programs. There are studies showing that donation rates have increased five times in four years through successful programs, mass media, distribution of posters and brochures, seminars and incentive visits to the anatomy museums (da Rocha et al.). It is reported that there is a gap between knowledge and motivation for organ and body donation, which should be filled with an appropriate guidance program and education (Saha et al.). The results of previous surveys show that ignorance is the main reason for the reluctance of body donation (Abbasi Asl et al.; Bamaç et al.; Ciliberti et al.).

Limitations. This study has some limitations. First, this is a cross-sectional study. The questionnaire form was developed by the researchers and no validity-reliability tests were performed. The study population consisted of 245 people and may not be considered as representative of Izmir province. However, results of the study offers evidence will provide insight on the subject in Izmir and Turkey.

\section{CONCLUSIONS}

The importance of cadaver in medical education and the awareness and knowledge level of the individuals in the society about cadaver donation are very important. The results in our survey was interpreted as indicators of the lack of 
knowledge of individuals about body donation. As high awareness and knowledge level will positively affect individuals' attitudes towards body donation, encouraging studies and programs on body donation will have a positive effect on cadaver donation and increase the donation rate.

The data obtained in our study provides important details about which part of the society has low level of knowledge about body donation. The results will also guide anatomists in Turkey about the informative and promotional activities on body donation should be focused on which parts of the society.

In particular, it will be useful to carry out body donation programs supported by public institutions through visual and written press. With the encouragement of these donation programs, we hope that body donation rates in our country can be increased to the required level.

ACKNOWLEDGEMENTS. The authors wish to thank Mustafa Tozun, MD for his valuable contributions to the statistical analysis of the data. The authors have no conflicts of interest to declare.

ERDOGAN, K.; ÖZEN, K. E.; YILDIZ, H. \& MALAS, M. A. Evaluación de conciencia, conocimiento y actitudes sobre la importancia del cadáver y la donación de cadáveres: Informe de Ismir, Turquía. Int. J. Morphol., 38(4):831-837, 2020.

RESUMEN: El objetivo de este estudio fue evaluar el nivel de conciencia, conocimiento y las actitudes de la comunidad en Izmir / Turquía sobre la donación de cadáveres en la educación médica. Se realizó un estudio transversal de 245 participantes elegidos al azar, que respondieron veinte ítems en el cuestionario proporcionando información sobre su demografía ( 5 ítems), conciencia y conocimiento (10 ítems) y actitudes (5 ítems) sobre la donación de cuerpos. El cuestionario fue administrado directamente en persona; la prueba T de Student y la prueba ANOVA de una vía se utilizaron para el análisis estadístico. De los participantes $123(50,2 \%)$ eran hombres y $159(64,9 \%)$ tenían entre 30 y 59 años. 185 $(75,5 \%)$ encuestados sabían lo que significa la palabra "cadáver". Cuando se les preguntó dónde se registrarían, en caso de decidir donar su cuerpo, $104(42,4 \%)$ de los participantes respondieron "hospital estatal". La puntuación media de conciencia y conocimiento sobre la importancia del cadáver y la donación de cuerpos (puntuación AWKL) fue de 0,41 $\pm 0,24$ (mínimo: 0,00, máximo: 0,90). Estadísticamente el puntaje AWKL fue más alto en los más jóvenes (18-29 años) y mayores (> 60 años) en comparación con los otros grupos etarios (F: 4,115; p: 0.007). AWKL-Score aumentó a medida que aumentó el nivel de educación. El puntaje AWKL más alto fue en el nivel de posgrado (Nivel 7,8) (F: 22,997; p <0,001). El puntaje AWKL fue mayor en empleados públicos y estudiantes en comparación con otros grupos ocupacionales (F: 5,930; p <0,001). Las respuestas al cuestionario fueron indicadores importantes de cuánto necesita la sociedad estar informada sobre la donación de cuerpos.

PALABRAS CLAVE: Donación de cuerpo; Cadáver; Nivel de conciencia y conocimiento; Actitud; Educación anatómica; Educación médica.

\section{REFERENCES}

Abbasi Asl, J.; Nikzad, H.; Taherian, A.; Atlasi, M. A.; Naderian, H.; Mousavi, G.; Kashani, M. M. \& Omidi, A. Cultural acceptability and personal willingness of Iranian students toward cadaveric donation. Anat. Sci. Educ., 10(2):120-6, 2017.

Bamaç, B.; Yener, M. D.; Çolak, T.; Tasdemir, R.; Aksu, E.; Güzelordu, D.; Sivri, I.; Örs, A. \& Çolak, S. Evaluation of attitudes and knowledge of Kocaeli University medical students on dissection, brain death and organ donation. Anatomy, 12(1):45-8, 2018.

Bøgh, L. \& Madsen, M. Attitudes, knowledge, and proficiency in relation to organ donation: a questionnaire-based analysis in donor hospitals in northern Denmark. Transplant. Proc., 37(8):3256-7, 2005.

Caplan, A. Bioethics of organ transplantation. Cold Spring Harb. Perspect. Med., 4(3):a015685, 2014.

Ciliberti, R.; Gulino, M.; Gazzaniga, V.; Gallo, F.; Vellone, V. G.; De Stefano, F.; Santi, P. \& Baldelli, I. A survey on the knowledge and attitudes of Italian medical students toward body donation: ethical and scientific considerations. J. Clin. Med., 7(7):E168, 2018.

da Rocha, A. O.; Tormes, D. A.; Lehmann, N.; Schwab, R. S. \& Canto, R. T. The body donation program at the Federal University of Health Sciences of Porto Alegre: a successful experience in Brazil. Anat. Sci. Educ., 6(3):199-204, 2013.

Dalal, A. R. Philosophy of organ donation: Review of ethical facets. World $J$. Transplant., 5(2):44-51, 2015.

Dinsmore, C. E.; Daugherty, S. \& Zeitz, H. J. Student responses to the gross anatomy laboratory in a medical curriculum. Clin. Anat., 14(3):231-6, 2001.

Dorland, W. A. N. Dorland's Illustrated Medical Dictionary. $32^{\text {nd }}$ ed. New York, Saunders, 2011.

Emson, H. E. The ethics of human cadaver organ transplantation: a biologist's viewpoint. J. Med. Ethics, 13(3):124-6, 1987.

Gatica-Araneda, J. P. \& Alfaro-Toloza, P. Donation of bodies for anatomy teaching in Chile. Anat. Sci. Educ., 7(3):248, 2014.

Gürses, I. A.; Coskun, O. \& Öztürk, A. Current status of cadaver sources in Turkey and a wake-up call for Turkish anatomists. Anat. Sci. Educ., 11(2): 155-65, 2018

Kleinman, I. \& Lowy, F. H. Cadaveric organ donation: ethical considerations for a new approach. CMAJ, 141(2):107-10, 1989.

Mekahli, D.; Liutkus, A.; Fargue, S.; Ranchin, B. \& Cochat, P. Survey of first-year medical students to assess their knowledge and attitudes toward organ transplantation and donation. Transplant. Proc., 41(2):634-8, 2009.

Saha, A.; Sarkar, A. \& Mandal, S. Body donation after death: the mental setup of educated people. J. Clin. Diagn. Res., 9(6):AC05-9, 2015.

Subasinghe, S. K. \& Jones, D. G. Human body donation programs in Sri Lanka: Buddhist perspectives. Anat. Sci. Educ., 8(5):484-9, 2015.

UNESCO. International Standard Classification of Education. ISCED 2011. Montreal, UNESCO Institute for Atatistics, 2012.

Wight, C.; Cohen, B.; Roels, L. \& Miranda, B. Donor action: a quality assurance program for intensive care units that increases organ donation. J. Intensive Care Med., 15(2):104-14, 2000.

Wingfield, H. A. Body donation today: a critical comparison of two current practices, and moving into the future. Clin. Anat., 31(1):86-9, 2018.

Corresponding author:

Kübra Erdogan, MD

Assistant Professor of Anatomy

Izmir Katip Çelebi Üniversitesi Tıp Fakültesi Anatomi AD

Çigli Ana Yerleskesi 35620

Çigli/lzmir

TURKEY

Received: 04-09-2019

Email: erdkubra@yahoo.com
Accepted: $15-02-2020$ 